\author{
JACEK PRZYGODZKI \\ ORCID: 0000-0003-2459-933X \\ Uniwersytet Wrocławski \\ Instytut Historii Państwa i Prawa \\ Zakład Historii Administracji
}

\title{
AKTYWNOŚĆ KONFERENCYJNA INSTYTUTU HISTORII PAŃSTWA I PRAWA UNIWERSYTETU WROCŁAWSKIEGO W LATACH 1969-2020
}

\begin{abstract}
Abstrakt: Celem artykułu jest przedstawienie aktywności konferencyjnej Instytutu Historii Państwa i Prawa w latach 1969-2020. W opisywanym okresie możemy zauważyć trzy rodzaje konferencji organizowanych przez jednostkę. Pierwsze to cykliczne, instytutowe konferencje o charakterze ogólnopolskim, kolejne to ogólnopolskie zjazdy katedr historyczno-prawnych oraz konferencje organizowane przez sekcję historyczno-prawną Koła Naukowego Prawników przekształconą następnie w Studenckie Koło Naukowe Historyków Państwa i Prawa działające przy Instytucie.

Słowa kluczowe: Wydział Prawa, Administracji Ekonomii UWr, Uniwersytet Wrocławski, Instytut Historii Państwa i Prawa, konferencje naukowe, jubileusz siedemdziesięciopięciolecia Wydziału Prawa
\end{abstract}

Jubileusz siedemdziesięciopięciolecia Wydziału Prawa, Administracji i Ekonomii Uniwersytetu Wrocławskiego jest okazją do dokonywania pewnych retrospekcji i ocen działalności naukowej jego jednostek organizacyjnych. W jubileuszowym, setnym tomie „Przeglądu Prawa i Administracji” wydanym z okazji siedemdziesięciolecia polskiego Wydziału Prawa we Wrocławiu znalazły się artykuły dotyczące organizacji i omawiające kierunki działalności zakładów Instytutu Historii Państwa i Prawa ${ }^{1}$, który jest częścią prawniczego fakultetu od 1945

1 M. Podkowski, Dzieje Zakładu Historii Administracji, „Przegląd Prawa i Administracji” 100, cz. 1. Księga Jubileuszowa Wydziału Prawa, Administracji i Ekonomii Uniwersytetu Wrockawskiego, red. M. Jabłoński, Wrocław 2015, s. 17-29; P. Jurek, Zakład Historii Państwa i Prawa Polski, ibidem, s. 31-48; J. Koredczuk, Dzieje Zakładu Powszechnej Historii Państwa i Prawa, ibidem, s. 49-68; A. Szymańska, Z dziejów katedry, a później Zakładu Prawa Rzymskiego Uniwersytetu Wrocławskiego (1945-2015), ibidem, s. 67-82. 
roku². Niniejszy artykuł jest próbą podsumowania działalności popularyzatorskiej Instytutu w postaci konferencji naukowych. Stanowią one bardzo ważny element życia naukowego każdego Uniwersytetu. Właśnie w czasie ich trwania naukowcy mogą zaprezentować swoje badania i skonfrontować je z poglądami innych badaczy. Wygłoszone referaty i przeprowadzona nad nimi dyskusja stanowią następnie kanwę do publikacji w monografiach, które zazwyczaj zawierają w sobie również pogłębioną refleksję autorów nad uwagami zgłoszonymi w trakcie konferencji.

Organizacja konferencji ulegała przeobrażeniom. W okresie PRL-u wyglądały one w ten sposób, że referaty na nich głosili zazwyczaj luminarze dyscyplin naukowych, a młodsi pracownicy naukowi mogli brać udział w dyskusji. Po 1989 roku ten system powoli zamierał, a od drugiej połowy lat dziewięćdziesiątych $\mathrm{XX}$ wieku zaczęto wprowadzać bardziej demokratyczny system wygłaszania referatów również przez niesamodzielnych pracowników naukowych, a później, po wprowadzeniu systemu studiów doktoranckich, także doktorantów.

W dziejach Instytutu Historii Państwa i Prawa możemy zauważyć trzy rodzaje konferencji: cykliczne, instytutowe konferencje o charakterze ogólnopolskim, ogólnopolskie zjazdy katedr oraz konferencje organizowane przez sekcję historyczno-prawną Koła Naukowego Prawników przekształconą następnie w Studenckie Koło Naukowe Historyków Państwa i Prawa działające przy Instytucie.

Inspiratorem cyklicznych konferencji organizowanych przez Instytut był luminarz jednostki prof. dr Kazimierz Orzechowski, pierwszy jej dyrektor pełniący tę funkcję od powstania w 1969 roku do przejścia na emeryturę w 1993 roku, który, nadal czynny naukowo, współpracował z Instytutem aż do śmierci (2009 rok). Profesor mawiał, że istnieje potrzeba cyklicznych — najlepiej corocznych - spotkań naukowych pracowników, w których uczestniczyliby również zaproszeni badacze z ośrodków krajowych. Na takich sympozjach pracownicy mogliby konfrontować swoje badania z poglądami innych naukowców.

Tę ideę postanowił wdrożyć w życie uczeń prof. K. Orzechowskiego, dr hab. Piotr Jurek, prof. UWr. W dniach od 29 września do 1 października 1997 roku w Karpaczu odbyła się pierwsza konferencja naukowa pod tytułem Podziały terytorialne Polski. Przeszłość - teraźniejszość — przyszłość. Prelegentami, oprócz pracowników naukowych Instytutu Historii Państwa i Prawa UWr oraz Wydziału Prawa i Administracji Uniwersytetu Gdańskiego, byli również pracownicy administracji rządowej i samorządowej. Swoje referaty wygłosili ówczesny wojewoda

2 O powołaniu katedr historyczno-prawnych, a następnie Instytutu Historii Państwa i Prawa zob. J. Koredczuk, 60-lecie powołania katedr historyczno-prawnych na Wydziale Prawa Uniwersytetu Wrocławskiego, „Prawo. Studia Historycznoprawne” 303, 2007; K. Jonca, Wydziat Prawa i Administracji Uniwersytetu Wrocławskiego 1945-1995, Wrocław 1996; K. Orzechowski, Katedra Historii Państwa i Prawa Polskiego na Wydziale Prawa Uniwersytetu Wrocławskiego, „Annales Silesiae I" 1960, z. 2; M.J. Ptak, Historia Wydziału Prawa, Administracji i Ekonomii Uniwersytetu Wroctawskiego, [w:] Wydział Prawa, Administracji i Ekonomii Uniwersytetu Wrocławskiego. Informator, Wrocław 2008. 
wrocławski Janusz Zaleski oraz prezes Regionalnej Izby Obrachunkowej dr Bogdan Cybulski, długoletni pracownik Instytutu. W czasie obrad przedstawiono dziewięć referatów. Oprócz wymienionych wystąpienia wygłosili: prof. Marian J. Ptak, prof. Edmund Klein, prof. Tadeusz Maciejewski z Gdańska, prof. Piotr Jurek, dr Józef Koredczuk, mgr Jacek Przygodzki i mgr Marek Podkowski. Zwieńczeniem konferencji był pierwszy tom konferencyjny pod redakcją naukową Piotra Jurka ${ }^{3}$.

Kolejna konferencja również odbyła się w Karpaczu — trwała od 7 do 9 września 1998 roku i zatytułowana była $W$ kręgu dziejów prawa karnego. Na konferencji wystąpiło piętnastu prelegentów. Jedenaście referatów wygłosili pracownicy wrocławskiego Wydziału Prawa, prelegentami byli również uczeni z Wydziału Prawa Uniwersytetu Gdańskiego i Bałtyckiej Wyższej Szkoły Humanistycznej w Koszalinie. Na podkreślenie zasługuje to, że dwa referaty przedstawili studenci wrocławskich stacjonarnych i niestacjonarnych studiów prawa. Tematyka wystąpień była bardzo szeroka - od prawa antycznego, poprzez czasy średniowiecza, nowożytność, II Rzeczpospolitą, okres II wojny światowej, PRL-u, jak i czasów najnowszych. Podsumowaniem konferencji była kolejna monografia o takim samym tytule co konferencja, a redaktorem naukowym został P. Jurek ${ }^{4}$.

Trzecia konferencja odbyła się w Karłowie w dniach od 7 do 9 września 1999 roku i zatytułowana była $W$ kręgu dziejów wymiaru sprawiedliwości. Do wygłoszenia referatów zgłosiło się osiemnastu prelegentów. Tym razem na liście znalazły się również wystąpienia studentów i doktorantów oraz zaproszonych gości z Bałtyckiej Wyższej Szkoły Humanistycznej w Koszalinie i Wydziału Prawa Uniwersytetu Mikołaja Kopernika w Toruniu. Możemy zauważyć, że konferencja kontynuowała tendencję bardzo szerokiego ujmowania zakresu tematycznego obejmującego historię powszechną, historię Polski oraz teorię i filozofię prawa. Pokłosiem konferencji była monografia pod redakcją P. Jurka ${ }^{5}$.

Kolejna konferencja poświęcona była siłom zbrojnym i prawu wojskowemu i odbyła się w Polanicy-Zdroju w dniach od 4 do 6 września 2000 roku. Wygłoszono na niej piętnaście referatów poświęconych prawu wojskowemu i dziejom wojskowości — od starożytności do czasów współczesnych. Większość wystąpień dotyczyła historii Polski, a jedna trzecia poświęcona była historii Śląska. Osobno należy wspomnieć, że pierwszy referat pod tytułem Część i całość w syntezujacych ujęciach dziejów ustrojowych wygłosił prof. Kazimierz Orzechowski. Wystąpienie zawierało wskazówki badawcze i wytyczne, które mogli wykorzystać

3 Podziaty terytorialne Polski. Przeszłość - teraźniejszość - przyszłość. Materiały konferencyjne historyków prawa w Karpaczu (29 IX-1 X 1997), red. P. Jurek, Wrocław 1997, s. 82.

${ }^{4} W$ kręgu dziejów prawa karnego. Materiaty II Konferencji historyków państwa i prawa. Karpacz 3-5.09.1998, red. P. Jurek, Wrocław 1999, s. 134.

5 W kręgu dziejów wymiaru sprawiedliwości. Materiały III Konferencji historyków państwa i prawa. Karłów 7-9 września 1999, red. P. Jurek, Wrocław 2000, s. 182. 
przede wszystkim młodsi pracownicy naukowi. Zwieńczeniem konferencji była kolejna monografia redagowana przez P. Jurka ${ }^{6}$.

Tematyką piątej konferencji, która odbyła się w dniach od 6 do 10 września 2001 roku w Świeradowie-Zdroju, była Wieś $i$ chłopi. Problemy ustrojowo-prawne. Osiemnastu referentów poświęciło swoje wystąpienia zagadnieniom z zakresu historii Polski i powszechnej historii państwa i prawa, począwszy od czasów antyku aż po współczesność. Większość referatów obejmowała kwestie dotyczące historii chłopów na ziemiach polskich z naciskiem na dzieje wsi śląskiej. Wśród prelegentów znaleźli się doktoranci przygotowujący dysertacje doktorskie w Instytucie. Referaty uzupełnione tezami z dyskusji prowadzonej w czasie konferencji zostały opublikowane w kolejnej monografii pod redakcją P. Jurka ${ }^{7}$.

Szósta konferencja zatytułowana Miasta i prawo miejskie w rozwoju historycznym miała miejsce w Lądku-Zdroju w dniach od 9 do 11 września 2002 roku. Wygłoszono na niej dziewiętnaście referatów obejmujących tematykę prawa miejskiego i organizacji miejskiej w historii powszechnej i polskiej, od średniowiecza do czasów współczesnych. Aż dziewięć wystąpień to referaty doktorantów, którzy mieli możliwość skonfrontowania swoich badań z opiniami innych uczestników sympozjum. Podsumowaniem konferencji była kolejna książka pod redakcją P. Jurka. Tom objął osiemnaście tekstów, ponieważ jeden z referentów nie złożył do publikacji swojego referatu ${ }^{8}$.

Kolejna konferencja odbyła się w Szklarskiej Porębie w dniach od 11 do 13 lipca 2003 roku i poświęcona była pozycji prawnej stanu szlacheckiego. Pierwszego dnia odbyła się specjalna sesja poświęcona jubileuszowi osiemdziesięciolecia luminarza Instytutu Historii Państwa i Prawa, prof. Kazimierza Orzechowskiego, na której ówczesny dziekan Wydziału Prawa, Administracji i Ekonomii UWr prof. Marek Bojarski wręczył jubilatowi księgę pamiątkową pod redakcją prof. Alfreda Koniecznego. Obrady merytoryczne zawierały siedemnaście referatów obejmujących tematykę pozycji ustrojowej szlachty, od rozwiązań prawa rzymskiego po czasy współczesne. Większość referatów poświęcona była tematyce z historii powszechnej. Kwintesencją konferencji była monografia, której redaktorem był P. Jurek ${ }^{9}$.

Ósma konferencja poświęcona została problematyce mniejszości narodowych na przestrzeni dziejów. Sympozjum odbyło się w Łagowie i trwało od 8 do 11 lipca 2004 roku. W jego trakcie odbyło się uroczyste wręczenie prof. zw. dr. hab. Alfredowi Koniecznemu, dyrektorowi Instytutu Historii Państwa i Prawa, księgi

${ }^{6}$ W kręgu dziejów sił zbrojnych i prawa wojskowego. Materiaty IV Konferencji historyków państwa i prawa. Polanica 4-6 września 2000, red. P. Jurek, Wrocław 2001, s. 165.

7 Wieś i chtopi. Materiały V Konferencji historyków państwa i prawa. Świeradów Zdrój 6-10 września 2001, red. P. Jurek,Wrocław 2002, s. 205.

${ }^{8}$ Miasta i prawo miejskie w rozwoju historycznym. Materiały VI Konferencji historyków państwa i prawa. Lądek Zdrój 9-11 września 2002, red. P. Jurek, Wrocław 2003, s. 212.

9 Pozycja prawna stanu szlacheckiego. Materiały VII Konferencji historyków państwa i prawa. Szklarska Poręba 11-13 lipca 2003, red. P. Jurek, Wrocław 2004, s. 216. 
pamiątkowej z okazji siedemdziesięciolecia urodzin. Uroczystą laudację wygłosił redaktor tomu, prof. Kazimierz Orzechowski. W części merytorycznej wygłoszono piętnaście referatów poświęconych mniejszościom od czasów rzymskich do współczesności. W konferencji wzięli udział również doktoranci przygotowujący swoje dysertacje w Instytucie. Podsumowaniem konferencji była kolejna monografia zredagowana przez prof. P. Jurka pod tytułem Mniejszości narodowe. Problemy ustrojowo-prawne ${ }^{10}$.

Tematyką dziewiątej konferencji było Postępowanie polubowne $w$ dziejach, a odbyła się ona w Przemyślu w dniach od 7 do 10 lipca 2005 roku. W czasie obrad wygłoszono dziesięć referatów o tematyce z zakresu historii powszechnej i historii Polski, od czasów antycznych do współczesności. Obradom przewodniczył — po raz pierwszy - nowy dyrektor Instytutu Historii Państwa i Prawa, prof. Marian Józef Ptak. W tomie pokonferencyjnym pod redakcją P. Jurka umieszczono cztery teksty przesłane przez trzech doktorantów Instytutu i dr. Wasyla Kisełyczynyka, adiunkta z Uniwersytetu imienia Iwana Franki we Lwowie, którzy nie mogli wziąć udziału w Konferencji11.

Dziesiąta, jubileuszowa konferencja poświęcona została Postępowaniu egzekucyjnemu $w$ dziejach. Obrady miały miejsce w Karpaczu w dniach od 11 do 13 września 2006 roku. W ich trakcie wygłoszono dziewiętnaście referatów z zakresu historii Polski i powszechnej historii państwa i prawa. Wystąpienia swoją tematyką obejmowały problemy prawa antycznego, prawa rzymskiego, średniowiecza, nowożytności oraz czasów najnowszych. W trakcie konferencji podsumowano również dotychczasowy system organizacji zjazdów. Decyzją dyrekcji Instytutu ustalono nowy system redakcji monografii pokonferencyjnych. Powołano Kolegium Redakcyjne pod przewodnictwem prof. Leonarda Górnickiego. Od kolejnego tomu redaktor miał być wybierany kolejno z każdego zakładu Instytutu Historii Państwa i Prawa. Dziesiąta monografia pokonferencyjna została zredagowana ostatni raz przez prof. P. Jurka. Oprócz referatów umieszczono tutaj spisy treści wszystkich wydanych dotychczas tomów ${ }^{12}$.

Przedmiotem jedenastej konferencji historyków państwa i prawa było Prawo wyznaniowe. Przeszłość i teraźniejszość. Odbyła się ona w Kowarach w dniach od 6 do 8 września 2007 roku. Szeroki zakres tematyczny pozwolił wygłosić siedemnaście referatów obejmujących okres od starożytności do czasów współczesnych z historii powszechnej, historii Polski, z naciskiem na historię Śląska, a dotyczących kościołów i związków wyznaniowych, stosunków państwo-Kościół i wolności sumienia i wyznania. Monografię pokonferencyjną Prawo wyznaniowe.

10 Mniejszości narodowe. Problemy ustrojowo-prawne. Materiały VIII Konferencji historyków państwa i prawa. Łagów 8-11 lipca 2004, red. P. Jurek, Wrocław 2005, s. 202.

11 Postepowanie polubowne $w$ dziejach. Materiały IX Konferencji historyków państwa i prawa. Przemyśl 7-10 lipca 2005, red. P. Jurek, Wrocław 2006, s. 192.

12 Postępowanie egzekucyjne $w$ dziejach. X Konferencja naukowa. Karpacz 11-13 września 2006, red. P. Jurek, Wrocław 2007, s. 245. 
Przeszłość i teraźniejszość zredagował Józef Koredczuk, a została ona podzielona na cztery części: „Wolność sumienia i wyznania”, „Wpływ Kościoła na rozwój prawa”, „Status prawny związków wyznaniowych i stosunki państwo-Kościół w Polsce”, „Status prawny związków wyznaniowych i stosunki państwo-Kościół w innych krajach ${ }^{13}$ ".

Kolejna konferencja odbyła się w Kudowie-Zdroju w dniach od 4 do 6 lipca 2008 roku. Poświęcona była skarbowości w dziejach. Wygłoszono na niej szesnaście referatów. Obejmowały one kwestie organizacji skarbowości, systemu podatków i ceł oraz obiegu pieniężnego w czasach starożytnych, poprzez średniowiecze, nowożytność aż po czasy współczesne. Referaty wygłaszali pracownicy naukowi oraz doktoranci Instytutu Historii Państwa i Prawa. Pokłosiem konferencji była monografia pod redakcją Rafała Wojciechowskiego pod tytułem $Z$ dziejów skarbowości, podzielona na trzy części: „Podatki i cła”, „Kwestie organizacyjne” i „Obieg pieniężny” 14 ”.

Trzynasta konferencja odbyła się w Świeradowie-Zdroju w dniach od 17 do 19 września 2009 roku. Jej tematem była Pozycja prawna kobiety $w$ dziejach. Wygłoszono na niej osiemnaście wystąpień. Ujmowały on tematykę w czasach antycznych, w tym prawodawstwa greckiego i rzymskiego, w historii Śląska, w wieku XIX i w pierwszej połowie wieku XX oraz w czasach najnowszych. Rozwinięciem referatów była monografia pod redakcją Stanisława Rogowskiego pod tytułem Pozycja prawna kobiety w dziejach. Tom ten autorzy poświęcili długoletniej sekretarce i współpracownicy Instytutu Historii Państwa i Prawa, mgr Danucie Wójcik ${ }^{15}$.

Tematem czternastej konferencji historyków państwa i prawa było Nauka i nauczenie prawa $w$ dziejach. Odbyła się ona w Lądku-Zdroju w dniach od 2 do 4 września 2010 roku. Na sympozjum wygłoszono trzynaście wystąpień. Obejmowały one kwestie dotyczące poglądów na nauczanie prawa wybitnych prawników, między innymi: Cinusa de Pistoi, Baldusa de Ubaldisa, Jana Kantego Czochrona, prof. Wacława Makowskiego, prof. Oswalda Balzera, prof. Axela von Freytagh-Loringhovenena, oraz nauki i nauczania prawa na Śląsku do XIX wieku czy nauki i nauczania procesu karnego II Rzeczypospolitej, a także zakresu unijnych programów badawczych. Podsumowaniem konferencji była publikacja książkowa pod redakcją naukową Tomasza Kruszewskiego ${ }^{16}$.

Piętnasta konferencja poświęcona została Rodzinie i jej prawom. Miejscem spotkania pracowników i doktorantów Instytutu Historii Państwa i Prawa oraz zaproszonych gości były Jugowice, a obrady trwały od 22 do 24 września 2011 roku. Czternastu prelegentów wygłosiło swoje referaty dotyczące zagadnień prawnych

13 Prawo wyznaniowe. Przeszłość i teraźniejszość. Materiały XI Konferencji historyków państwa i prawa. Kowary 6-8 września 2007 r., red. J. Koredczuk, Wrocław 2008, s. 301.

${ }^{14} Z$ dziejów skarbowości, red. R. Wojciechowski, Wrocław 2009, s. 246.

15 Pozycja prawna kobiety w dziejach, red. S. Rogowski, Wrocław 2010, s. 269.

16 Nauka i nauczenie prawa w dziejach, red. T. Kruszewski, Wrocław 2011, s. 186. 
związanych $\mathrm{z}$ funkcjonowaniem rodziny $\mathrm{w}$ prawach antycznych — ateńskim i rzymskim, w średniowieczu, w prawodawstwie siedemnastowiecznego Śląska oraz w XIX i XX wieku. Redaktorem tomu powstałego na kanwie konferencji był Jarosław Rominkiewicz. Autorzy opublikowane teksty poświęcili przechodzącemu na emeryturę dr. Stanisławowi Rogowskiemu ${ }^{17}$.

Kolejna konferencja odbyła się w dniach od 27 do 29 września 2012 roku w Jakuszycach. Jej tematem był Samorzą i samorzadność w przeszłości i teraźniejszości. Na zjeździe wygłoszono czternaście referatów, które swoją tematyką obejmowały zagadnienia prawa ateńskiego i rzymskiego, średniowiecznego Śląska oraz ziem polskich po zakończeniu I i II wojny światowej. Redaktorem monografii wydanej na kanwie wygłoszonych wystąpień i przeprowadzonej dyskusji został Marian J. Ptak. Jednak tom składał się z jedenastu tekstów, ponieważ trzech prelegentów nie złożyło swoich referatów ${ }^{18}$.

Tematem siedemnastej konferencji historyków państwa i prawa, która odbyła się w Dusznikach-Zdroju, było Dziecko i jego pozycja prawna w dziejach. Swoje wystąpienia zgłosiło siedemnastu prelegentów z ośrodka wrocławskiego, jak również z Torunia i Lublina. Obejmowały one tematykę pozycji prawnej dzieci w historii Polski i historii powszechnej, w szczególności w czasach antyku, prawie średniowiecznym, w nowożytności, w XIX i XX wieku. W wyniku ożywionej dyskusji powstała monografia pod takim samym tytułem, a jej redaktorem został Andrzej Pasek. Składała się ona z piętnastu części, ponieważ dwóch referujących nie przesłało swoich tekstów do druku. Autorzy zadedykowali przygotowany tom przechodzącemu na emeryturę dr. Ireneuszowi Żeberowi ${ }^{19}$.

Osiemnasta konferencja odbyła się w dniach od 11 do 13 września 2014 roku w Dusznikach-Zdroju, a zatytułowana była Zasady prawne $w$ dziejach prawa publicznego i prywatnego. Obradom przewodniczył dyrektor Instytutu Historii Państwa i Prawa, prof. M.J. Ptak. Wygłoszono piętnaście referatów. Obejmowały one kwestie dotyczące pewnych zasad, które w prawie publicznym i prywatnym (na tle innych, zwykłych norm prawnych) wyróżniają się ponadprzeciętną doniosłością aksjologiczną, funkcjonalną i hierarchiczną ${ }^{20}$. Wystąpienia wygłoszone przez badaczy z ośrodków naukowych wrocławskiego i toruńskiego obejmowały czasy starożytności, średniowiecza, ustroju Śląska i Rzeczypospolitej szlacheckiej, siedemnastowiecznej Danii, okresu XIX i XX wieku. W zjeździe wzięli również pracownicy naukowi z Uniwersytetu imienia Adama Mickiewicza w Poznaniu, którzy aktywnie uczestniczyli w dyskusji nad wygłoszonymi wystąpieniami. Zwieńcze-

17 Rodzina i jej prawa, red. R. Rominkiewicz, Wrocław 2012, s. 218.

18 Samorząd i samorzadność w przeszłości i teraźniejszości, red. M.J. Ptak, Wrocław 2013, s. 202.

19 Dziecko i jego pozycja prawna w dziejach, red. A. Pasek, Wrocław 2014, s. 287.

20 L. Leszczyński, G. Maroń, Pojęcie i treść zasad prawa oraz generalnych klauzul odsyłajacych. Uwagi porównawcze, „Annales Universitas Mariae Curie-Skłodowska”, XL, Sectio G, Lublin 2013, s. 81. 
niem konferencji była publikacja kolejnej monografii. Jej redaktorem naukowym został Marek Podkowski. Składała się ona trzynastu rozdziałów, dwóch prelegentów nie przesłało bowiem wygłoszonych referatów do druku ${ }^{21}$.

Tematem kolejnej konferencji był Honor, cześć, godność — aspekty historyczno-prawne. Odbyła się ona w Polanicy-Zdroju w dniach od 17 do 19 września 2015 roku. Stanowiła ona również jeden z elementów jubileuszu siedemdziesięciolecia polskiego środowiska akademickiego we Wrocławiu. Osiemnastu referentów z Poznania, Torunia i Wrocławia przygotowało wystąpienia z zakresu powszechnej historii państwa i prawa oraz historii Polski od czasów antycznych do współczesności, podkreślając wagę tematycznych wartości w życiu społecznych, jak i w wymiarze jednostkowym. Redaktorem monografii zbiorowej podsumowującej konferencję został Paweł Wiązek. Składała się ona z piętnastu rozdziałów, trzech prelegentów nie przesłało do druku swoich wystąpień 22 .

Dwudziesta, jubileuszowa konferencja poświęcona została Regulacjom prawnym gospodarki w rozwoju historycznym, a odbyła się w Starej Morawie w dniach od 22 do 24 września 2016 roku. Wzięli w niej udział historycy prawa z Katowic, Poznania, Torunia i Wrocławia. Do programu zjazdu zgłoszono siedemnaście referatów, wygłoszono jednak szesnaście wystąpień, ponieważ jeden z prelegentów nie dojechał na obrady. Obejmowały one tematykę regulacji prawnych gospodarki z prawa greckiego, średniowiecznego, prawodawstwa Śląska i Rzeczypospolitej szlacheckiej oraz XIX i XX wieku. Monografia pokonferencyjna zawarła w sobie już wszystkie wystąpienia poszerzone tezami z dyskusji przeprowadzonej na sympozjum. W tomie umieszczono wykaz poprzednich cyklicznych konferencji zorganizowanych przez Instytut Historii Państwa i Prawa. Redaktorką naukową została Aleksandra Szymańska. Monografię autorzy zadedykowali przechodzącym na emeryturę pracownikom naukowym Instytutu — dr. hab. Piotrowi Jurkowi, prof. UWr, i dr. Markowi Kinstlerowi ${ }^{23}$.

Kolejna konferencja odbyła się w Polanicy-Zdroju w dniach od 21 do 23 września 2017 roku. Jej tematem były Regulacje prawne dotyczace malżeństwa w rozwoju historycznym. Swoje wystąpienia wygłosili badacze z Gdyni, Poznania, Torunia, Wałbrzycha i Wrocławia. Osiemnaście referatów zawierało informacje o zmieniających się regulacjach prawnych dotyczących małżeństwa w prawach antycznych, prawie rzymskim, w średniowiecznej Szkocji i Danii, na Śląsku, w okresie Rzeczypospolitej szlacheckiej, rozbiorów, II Rzeczypospolitej i po zakończeniu

${ }^{21}$ Zasady prawne w dziejach prawa publicznego i prywatnego, red. M. Podkowski, Wrocław 2015, s. 215.

${ }^{22}$ Honor, cześć, godność - aspekty historyczno-prawne, red. P. Wiązek, Wrocław 2016, s. 248.

23 Regulacje prawne gospodarki w rozwoju historycznym, red. A. Szymańska, Wrocław 2017, s. 265 . 
II wojny światowej. Monografia złożona z piętnastu rozdziałów (trzech prelegentów nie przesłało tekstów do druku) zredagowana została przez Tomasza Dolatę ${ }^{24}$.

Dwudziesta druga konferencja historyków państwa i prawa odbyła się w Polanicy-Zdroju w dniach od 27 do 29 września 2018 roku. Jej tematem były Okresy przejściowe - ustrój i prawo. Do programu zjazdu zgłoszono piętnaście referatów obejmujących tematykę okresów przejściowych jako szczególnych w historii państwa i prawa, kiedy zazwyczaj kończą się „stare rządy”, a powstają nowe struktury państwowe czy rozstrzygnięcia prawne. Wystąpienia poświęcone były czasom od średniowiecza do współczesności. Referaty wzbudziły gorącą dyskusję, w której brali udział zaproszeni goście z Katowic, Torunia czy Wałbrzycha. Kwintesencją referatów i prowadzonej dyskusji była monografia zredagowana przez Jacka Przygodzkiego. Zawierała ona trzynaście rozdziałów, ponieważ dwie osoby nie przesłały swoich wystąpieńn ${ }^{25}$.

Ostatnia konferencja odbyła się w Polanicy-Zdroju w dniach od 19 do 21 września 2019 roku, a poświęcona była Handlowi w dziejach państwa i pra$w a$. W czasie konferencji prof. Józef Koredczuk wygłosił okolicznościowy referat z okazji pięćdziesięciolecia istnienia Instytutu Historii Państwa i Prawa. Pozostałe siedemnaście wystąpień poświęconych było szeroko pojmowanemu handlowi i jego regulacjom prawnym. Prelegenci pochylili się nad kwestiami handlu w prawie greckim, rzymskim, średniowiecznym prawie włoskim, hanzeatyckim, śląskim, szkockim, francuskim, amerykańskim, prawodawstwie zaborczym i okresu II Rzeczypospolitej. Referaty wzbudziły gorącą dyskusję ${ }^{26}$. Na konferencji ustalono, że kolejnym redaktorem naukowym monografii wieńczącej sympozjum będzie dr Dobromiła Nowicka.

Instytut współorganizował również trzy konferencje z Katedrą Doktryn Politycznych i Prawnych UWr. Pierwsza odbyła się w Kudowie-Zdroju w dniach od 19 do 21 kwietnia 2006 roku, a jej temat to Wybitni prawnicy na przestrzeni wieków. Tematem drugiej konferencji byli Prawnicy na Uniwersytecie Wrockawskim. Obrady trwały od 27 do 29 września 2011 roku, a miejscem spotkania uczestników zjazdu była Polanica Zdrój. Trzecia konferencja zatytułowana była Pro publico bono - idee i działalność. Obradowano w dniach od 16 do 17 kwietnia 2015 roku w Polanicy-Zdroju ${ }^{27}$.

${ }^{24}$ Regulacje prawne dotyczace matżeństwa w rozwoju historycznym, red. T. Dolata, Wrocław 2018, s. 258.

25 Okresy przejściowe - ustrój i prawo, red. J. Przygodzki, Wrocław 2019, s. 217.

${ }^{26}$ Program XXIII Konferencji historyków państwa i prawa/Handel w dziejach państwa i prawa znajdujący się w posiadaniu autora artykułu.

27 Wybitni prawnicy na przestrzeni wieków, red. M. Marszał, J. Przygodzki, Wrocław 2006, s. 270; Prawnicy na Uniwersytecie Wrocławskim, red. M. Marszał, J. Przygodzki, Wrocław 2012, s. 151; „Pro publico bono”: idee i dziatalność, red. M. Marszał, J. Przygodzki, „e-Monografie” 2016, nr 84, s. 207. Dostęp również on-line: http://www.bibliotekacyfrowa.pl/publication/80075 (dostęp: 30.11.2016). 
Kolejną grupą konferencji organizowanych przez Instytut Historii Państwa i Prawa UWr były ogólnopolskie zjazdy katedr historyczno-prawnych. Ośrodek wrocławski został gospodarzem pierwszego takiego zjazdu w 1964 roku, jeszcze przed powołaniem struktury instytutowej. Konferencja odbyła się w Karpaczu w dniach od 11 do 13 czerwca. W trakcie obrad wygłoszono pięć referatów pierwszy: dotyczący Stanu nauki historii państwa i prawa na tle ogólnej sytuacji nauk prawnych w latach 1960-1963 wygłosił prof. Jan Wąsicki z Uniwersytetu im. Adama Mickiewicza w Poznaniu; drugi: Programy studiów: historii państwa i prawa polskiego wygłosił prof. Zdzisław Kaczmarczyk z Uniwersytetu im. Adama Mickiewicza w Poznaniu, ...powszechnej historii państwa i prawa wygłosił doc. dr Zbigniew Zdrójkowski z Uniwersytetu Mikołaja Kopernika w Toruniu, ...prawa rzymskiego wygłosił prof. Wacław Osuchowski z Uniwersytetu Jagiellońskiego, ...doktryn politycznych i prawnych wygłosił doc. dr Jan Baszkiewicz z Uniwersytetu Wrocławskiego; trzeci: Nauki historyczno-prawne i ich miejsce w systemie ksztatcenia prawniczego wygłosił prof. Juliusz Bardach z Uniwersytetu Warszawskiego; czwarty: Ćwiczenia z przedmiotów historyczno-prawnych (na podstawie doświadczeń Uniwersytetu Warszawskiego) wygłosili dr Stanisław Russocki, dr Katarzyna Sójka-Zielińska, dr Krystyna Bukowska; piąty: Prace magisterskie i seminaria magisterskie z historii prawa wygłosił prof. Kazimierz Orzechowski z Uniwersytetu Wrocławskiego ${ }^{28}$.

Kolejny ogólnopolski zjazd katedr Instytut Historii Państwa i Prawa współorganizował w Karpaczu w dniach od 23 do 25 maja 1974 roku. Jego tematem były Dzieje kodyfikacji prawa. W konferencji wzięło udział ponad osiemdziesiąt osób reprezentujących wszystkie ośrodki akademickie i Instytut Historii Polskiej Akademii Nauk. Referaty przygotowane do wygłoszenia zostały opublikowane przed rozpoczęciem obrad ${ }^{29}$, dlatego uczestnicy zjazdu mieli dodatkowy czas na przeprowadzenie gruntownej dyskusji nie tylko nad zgłoszonymi referatami, ale również nad kwestią reformy uniwersyteckich studiów prawniczych. Asumptem do burzliwej dyskusji była obecność na konferencji prof. Jana Baszkiewicza, który był członkiem komisji przygotowującej nowy program studiów ${ }^{30}$.

Trzeci ogólnopolski zjazd katedr historyczno-prawnych ośrodek wrocławski zorganizował — tradycyjnie — w Karpaczu w dniach od 8 do 10 września 1988 roku. Wzięło w nim udział ponad pięćdziesięciu uczestników. Tematem konferencji były Regionalne syntezy dziejów ustroju i prawa. Referaty wygłosili prof. Kazimierz

28 Konferencja katedr historycznoprawnych w Karpaczu, „Czasopismo Prawno-Historyczne” (dalej: CPH) 17, 1965, z. 2, s. 319.

${ }^{29}$ Dzieje kodyfikacji prawa. Materiały na konferencję historyków prawa w Karpaczu, Polskie Towarzystwo Historyczne, Komisja Historyczno-Prawna, Karpacz 1974, s. 175.

30 M. Sędek, A. Zakrzewski, Dzieje kodyfikacji prawa. Ogólnopolska konferencja historyków państwa i prawa w Karpaczu, CPH 27, 1975, z. 1, s. 202-207. 
Orzechowski, doc. Franciszek Połomski, prof. Alfred Konieczny, prof. Hubert Izdebski, prof. Stanisław Russocki, prof. Stanisław Grodziski, doc. Adam Lityński ${ }^{31}$.

Największy, XXII zjazd historyków państwa i prawa Instytut zorganizował w Kliczkowie w dniach od 18 do 21 września 2008 roku. Jego tematem było Spoteczeństwo a władza. Ustrój, prawo, idee. Temat został szeroko zakreślony, aby możliwość wygłoszenia referatów mieli przedstawiciele wszystkich dyscyplin historyczno-prawnych, począwszy od prawa antycznego, historii doktryn politycznych i prawnych, powszechnej historii państwa i prawa oraz historii państwa i prawa polskiego. Udział w zjeździe zadeklarowały 172 osoby. Ostatecznie przybyło 166 uczestników, w tym 41 profesorów, 8 doktorów habilitowanych, 79 doktorów i 38 magistrów, którzy reprezentowali szesnaście uniwersytetów, dwie państwowe wyższe szkoły zawodowe, cztery niepubliczne szkoły wyższe, dwie zagraniczne uczelnie wyższe oraz przedstawiciel Instytutu Pamięci Narodowej oddział w Krakowie. Prelegentami na sesji plenarnej w kolejności byli: prof. dr hab. Wacław Uruszczak z Uniwersytetu Jagiellońskiego w Krakowie, ks. prof. dr hab. Florian Lempa z Uniwersytetu w Białymstoku, prof. dr hab. Marian J. Ptak z Uniwersytetu Wrocławskiego, prof. dr hab. Ryszard M. Małajny z Uniwersytetu Śląskiego w Katowicach, prof. dr hab. Marek Maciejewski reprezentujący Uniwersytet Wrocławski i Opolski oraz prof. dr hab. Maria Zmierczak z Uniwersytetu imienia Adama Mickiewicza w Poznaniu. W czasie obrad w sekcjach referenci wygłosili 79 referatów ${ }^{32}$. Pokłosiem zjazdu była monografia Społeczeństwo a władza. Ustrój, prawo, idee pod redakcją Jacka Przygodzkiego i Mariana J. Ptaka ${ }^{33}$.

Ostatnią grupą konferencji były sympozja organizowane przez Studenckie Koło Naukowe Prawników, sekcję Historyczno-Prawną, przekształconą później w Studenckie Koło Naukowe (dalej: SKN) Historii Państwa i Prawa. Pierwszą współorganizowaną konferencją była 20 lat samorządu terytorialnego w II i III Rzeczypospolitej. I Wydziałowa Konferencja Kół Naukowych Wydziału Prawa, Administracji i Ekonomii Uniwersytetu Wrocławskiego, która odbyła się w 2010 roku. Kolejne sympozjum odbyło się w 2014 roku. SKN Historii Państwa i Prawa oraz SKN Prawa Rzymskiego i Porównawczego zorganizowały ogólnopolską konferencję naukową pod tytułem Centrum a peryferie na przestrzeni dziejów. W 2015 roku SKN Historii Państwa i Prawa oraz SKN Doktryn Politycznych i Prawnych Uniwersytetu Wrocławskiego zorganizowały ogólnopolską konferencję naukową Państwo a gospodarka na przestrzeni dziejów”. Dnia 26 maja 2018 roku odbył się Studencki Piknik Samorzadowy. XX lat Wrocławia - miasta na prawach powiatu. III Wydziałowa Konferencja Studenckich Kół Naukowych Wydziału Prawa, Administracji i Ekonomii Uniwersytetu Wrocławskiego współorganizowany przez

31 P. Jurek, J. Koredczuk, Zjazd historyków prawa w Karpaczu, CPH 42, 1990, z. 1-2, s. 213.

32 J. Przygodzki, XXII Ogólnopolski Zjazd Historyków Państwa i Prawa w Kliczkowie (18-21 września 2008), CPH 51, 2009, z. 1, s. 409-411.

33 Spoteczeństwo a władza. Ustrój, prawo, idee, red. J. Przygodzki, M.J. Ptak, Wrocław 2010, s. 1057. 
SKN Historii Państwa i Prawa. Ostatnia konferencja przygotowana przez historyczno-prawne SKN odbyła się 24 maja 2019 roku we Wrocławiu i nosiła tytuł Mniejszości narodowe w dziejach. Problemy ustrojowo - prawne $e^{34}$.

Podsumowując aktywność konferencyjną Instytutu Historii Państwa i Prawa, możemy zauważyć, że w pierwszym okresie swojej działalności jednostka organizowała głównie ogólnopolskie zjazdy katedr historyczno-prawnych. Nie próbowano wtedy tworzyć mniejszych sympozjów oraz konferencji z udziałem studentów. Zmieniło się to po 1989 roku, kiedy zaczęto zauważać popularyzatorską rolę uniwersytetów. Zwrócono też uwagę, że aktywny udział w konferencjach młodszych pracowników nauki pozwoli na konfrontowanie ich badań z poglądami naukowców z innych ośrodków akademickich.

Należy zauważyć, że dwadzieścia trzy cykliczne konferencje Instytutu dają możliwość corocznego aktywizowania wszystkich pracowników jednostki, którzy przygotowują swoje wystąpienia i bronią prezentowanych poglądów $\mathrm{w}$ trakcie dyskusji prowadzonych na zjeździe. Następnie wystąpienia stanowią kanwę corocznych publikacji pracowników, które przekładają się na ocenę jednostki.

Nowym trendem w popularyzowaniu nauki jest aktywizowanie studentów Wydziału. Organizując konferencje i głosząc tam swoje pierwsze referaty oraz publikując je w materiałach pokonferencyjnych, przygotowują się oni do późniejszej pracy naukowej. Taka tendencja jest spójna ze strategią wdrażania studentów w badania naukowe prezentowaną przez Ministerstwo Nauki i Szkolnictwa Wyższego.

\title{
ACADEMIC CONFERENCES OF THE INSTITUTE OF HISTORY OF STATE AND LAW \\ AT THE UNIVERSITY OF WROCŁAW (1969-2020)
}

\author{
Summary
}

The aim of the article is to present the academic conferences of the Institute of History of State and Law from 1969 to 2020. In the aforementioned period there are three types of conferences organised by the Institute. The first of these are cyclical conferences of a national character, the next are congresses of departments of legal history from universities across Poland, and the last are the conferences organised by students gathered firstly in the department of legal history in the Lawyer's Student Research Group, which later transformed into the Student's Legal History Research Group.

Keywords: Faculty of Law, Administration and Economics, University of Wrocław, Institute of History of State and Law, academic conferences, the 75th anniversary of the Faculty of Law, Administration and Economics

34 Informacje uzyskane od opiekuna SKN Historii Państwa i Prawa dr. Marka Podkowskiego. 


\section{BIBLIOGRAFIA}

Dziecko i jego pozycja prawna w dziejach, red. A. Pasek, Wrocław 2014.

Dzieje kodyfikacji prawa. Materiały na konferencję historyków prawa w Karpaczu, Polskie Towarzystwo Historyczne, Komisja Historyczno-Prawna, Karpacz 1974.

Honor, cześć, godność - aspekty historyczno-prawne, red. P. Wiązek, Wrocław 2016.

Jonca K., Wydziat Prawa i Administracji Uniwersytetu Wrocławskiego 1945-1995, Wrocław 1996.

Jurek P., Zakład Historii Państwa i Prawa Polski, „Przegląd Prawa i Administracji” 100, cz. 1. Księga Jubileuszowa Wydziału Prawa, Administracji i Ekonomii Uniwersytetu Wrocławskiego, red. M. Jabłoński, Wrocław 2015.

Jurek P., Koredczuk J., Zjazd historyków prawa w Karpaczu, „Czasopismo Prawno-Historyczne” 42, 1990, z. 1-2.

Konferencja katedr historycznoprawnych w Karpaczu, „Czasopismo Prawno-Historyczne” 17, 1965, z. 2 , s. 319.

Koredczuk J., 60-lecie powołania katedr historyczno-prawnych na Wydziale Prawa Uniwersytetu Wroctawskiego, „Prawo. Studia Historycznoprawne” 303, 2007.

Koredczuk J., Dzieje Zakładu Powszechnej Historii Państwa i Prawa, „Przegląd Prawa i Administracji” 100, cz. 1. Księa Jubileuszowa Wydziatu Prawa, Administracji i Ekonomii Uniwersytetu Wrocławskiego, red. M. Jabłoński, Wrocław 2015.

Leszczyński L., Maroń G., Pojęcie i treść zasad prawa oraz generalnych klauzul odsyłających. Uwagi porównawcze, „Annales Universitas Mariae Curie-Skłodowska”, XL, Sectio G, Lublin 2013.

Miasta i prawo miejskie w rozwoju historycznym. Materiaty VI Konferencji historyków państwa i prawa. Lądek Zdrój 9-11 września 2002, red. P. Jurek, Wrocław 2003.

Mniejszości narodowe. Problemy ustrojowo-prawne. Materiały VIII Konferencji historyków państwa i prawa. Łagów 8-11 lipca 2004, red. P. Jurek, Wrocław 2005.

Nauka i nauczenie prawa w dziejach, red. T. Kruszewski, Wrocław 2011.

Okresy przejściowe - ustrój i prawo, red. J. Przygodzki, Wrocław 2019.

Orzechowski K., Katedra Historii Państwa i Prawa Polskiego na Wydziale Prawa Uniwersytetu Wroctawskiego, „Annales Silesiae I” 1960, z. 2.

Podkowski M., Dzieje Zakładu Historii Administracji, „Przegląd Prawa i Administracji” 100, cz. 1. Księga Jubileuszowa Wydziału Prawa, Administracji i Ekonomii Uniwersytetu Wrocławskiego, red. M. Jabłoński, Wrocław 2015, s. 17-29.

Podziały terytorialne Polski. Przeszłość - teraźniejszość - przyszłość. Materiały konferencyjne historyków prawa w Karpaczu (29 IX-1 X 1997), red. P. Jurek, Wrocław 1997.

Postepowanie egzekucyjne w dziejach. X Konferencja naukowa. Karpacz 11-13 września 2006, red. P. Jurek, Wrocław 2007.

Postępowanie polubowne $w$ dziejach. Materiały IX Konferencji historyków państwa i prawa. Przemyśl 7-10 lipca 2005, red. P. Jurek, Wrocław 2006.

Pozycja prawna kobiety w dziejach, red. S. Rogowski, Wrocław 2010.

Pozycja prawna stanu szlacheckiego. Materiaty VII Konferencji historyków państwa i prawa. Szklarska Poręba 11-13 lipca 2003, red. P. Jurek, Wrocław 2004.

Prawnicy na Uniwersytecie Wrocławskim, red. M. Marszał, J. Przygodzki, Wrocław 2012.

Prawo wyznaniowe. Przeszłość i teraźniejszość. Materiaty XI Konferencji historyków państwa i prawa. Kowary 6-8 września 2007 r., red. J. Koredczuk, Wrocław 2008.

Program XXIII Konferencji historyków państwa i prawa/Handel w dziejach państwa i prawa znajdujący się w posiadaniu autora artykułu.

„Pro publico bono”: idee i działalność, red. M. Marszał, J. Przygodzki, „e-Monografie” 2016, nr 84. Dostęp również online: http://www.bibliotekacyfrowa.pl/publication/80075 (dostęp: 30.11.2016). 
Przygodzki J., XXII Ogólnopolski Zjazd Historyków Państwa i Prawa w Kliczkowie (18-21 września 2008), „Czasopismo Prawno-Historyczne” 61, 2009, z. 1.

Ptak M.J., Historia Wydziału Prawa, Administracji i Ekonomii Uniwersytetu Wrocławskiego, [w:] Wydziat Prawa, Administracji i Ekonomii Uniwersytetu Wrocławskiego. Informator, Wrocław 2008.

Regulacje prawne dotyczace małżeństwa w rozwoju historycznym, red. T. Dolata, Wrocław 2018.

Regulacje prawne gospodarki w rozwoju historycznym, red. A. Szymańska, Wrocław 2017.

Rodzina i jej prawa, red. R. Rominkiewicz, Wrocław 2012.

Samorzą i samorządność w przeszłości i teraźniejszości, red. M.J. Ptak, Wrocław 2013.

Sędek M., Zakrzewski A., Dzieje kodyfikacji prawa. Ogólnopolska konferencja historyków państwa i prawa w Karpaczu, „Czasopismo Prawno-Historyczne” 27, 1975, z. 1, s. 202-207.

Społeczeństwo a władza. Ustrój, prawo, idee, red. J. Przygodzki, M.J. Ptak, Wrocław 2010.

Szymańska A., Z dziejów katedry, a później Zaktadu Prawa Rzymskiego Uniwersytetu Wrocławskiego (1945-2015), „Przegląd Prawa i Administracji” 100, cz. 1. Ksiega Jubileuszowa Wydziału Prawa, Administracji i Ekonomii Uniwersytetu Wrocławskiego, red. M. Jabłoński, Wrocław 2015.

W kręgu dziejów prawa karnego. Materiały II Konferencji historyków państwa i prawa. Karpacz 3-5.09.1998, red. P. Jurek, Wrocław 1999.

W kręgu dziejów sił zbrojnych i prawa wojskowego. Materiały IV Konferencji historyków państwa i prawa. Polanica 4-6 września 2000, red. P. Jurek, Wrocław 2001.

W kręgu dziejów wymiaru sprawiedliwości. Materiaty III Konferencji historyków państwa i prawa. Karłów 7-9 września 1999, red. P. Jurek, Wrocław 2000.

Wieś i chłopi. Materiały V Konferencji historyków państwa i prawa. Świeradów Zdrój 6-10 września 2001, red. P. Jurek, Wrocław 2002.

Wybitni prawnicy na przestrzeni wieków, red. M. Marszał, J. Przygodzki, Wrocław 2006.

Z dziejów skarbowości, red. R. Wojciechowski, Wrocław 2009.

Zasady prawne w dziejach prawa publicznego i prywatnego, red. M. Podkowski, Wrocław 2015. 